\title{
Öğretmenlerin Görüşleri Işığında Aile Birliğini Korumada Değerlerin Rolüne Fenemolojik Bir Bakış ${ }^{*}$
}

\section{A phenological View an Unity of Family with the Role of Morals in the Light of Teachers' Vision}

\author{
Halil İbrahim SAĞLAM $^{\star *} \quad$ Duygu ÖZDEMIR $^{* * *}$
}

Öz. Bu araştırmanın amacı öğretmenlerin görüşleri ışığında aile birliğini korumada değerlerin rolünü belirlemektir. Araştırmanın çalışma grubunu 2014-2015 eğitim öğretim yılında Kocaeli ilinin Körfez ilçesinde görev yapan 24'ü kadın, 11'i erkek olmak üzere toplam 35 öğretmen oluşturmaktadır. Araştırma, nitel araştırma desenlerinden olgu bilim deseni kapsamında yürütülmüştür. Araştırmada yarı yapılandırıımış görüşme formu kullanılmıştır. İki bölümden oluşan görüşme formunun birinc bölümünde öğretmenlerinin kişisel bilgilerini, ikinci bölümünde öğretmenlerin aile birliğini devam ettirmede değerlerin rolüne ilişkin görüşlerini yansıtacak sorulara yer verilmiştir. Görüşme formundaki soruların kapsam geçerliği için alanla ilgili üç uzmanın görüşüne başvurulmuş ve gelen öneriler doğrultusunda gerekli düzeltmeler yapılmıştır. Ayrıca, görüşme formundaki soruların anlaşılılığı ikisi sınıf, ikisi branş öğretmeni olmak üzere toplam dört öğretmenle görüşülerek forma son şekl verilmiştir. Veriler içerik analizi ile çözümlenmiştir. Araştırmada; sevgi, saygı, sabır, sadakat, sorumluluk ve hoşgörü değerlerinin aile bireylerinin bir arada yaşamasında önemli rol oynadığı sonucuna ulaşılmıştır.

Anahtar Kelimeler: Öğretmen, değer, aile birliğine önem verme.

\begin{abstract}
The aim of this survey is to specify the role of the morals to sustain the unity family. The study group of the project is formad by twenty four female teachers, eleven male teacher's phonological style. Semi-structured interviev form is used duringthe study. The interviev form is formed by two parts. In the first part there is the personal information of the teachers and in the other part there are a sume question that answers the opinions of the teachers about unity of family. For the content validity of the interviev form, three experts were consulted and revised according to their suggestions. And Also the intelligibilityof the questions on the form were revised by different branches of teachers and the ullimate form was given to the study. The data acquired from the teachers was resolved in the way of content analysis. At the end of the study it was made out that, favour, respect, patience, loyalty responsibility and tolerance morals are the keystones for sustaining the unity of family.
\end{abstract}

Keywords: Teacher, value, attaching importance to conjugal community.

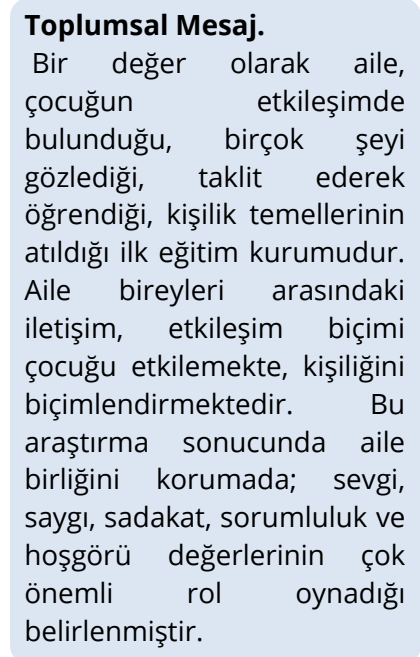

Public Interest Statement. As a value, family is the first education institution where the child is interactive, observes many things, learns by imitation, the foundations of his/her personality are laid. The communication, interaction method between the family members affects the child, shapes his/her personality. As result of this research, it is determined that love, respect, loyalty, responsibility and tolerance values play very important part in protecting the conjugal community.

\footnotetext{
* Bu makale VII. Ulusal Lisansüstü Eğitim Sempozyumu'nda bir kısmı sözlü bildiri olarak sunulan çalışmanın tamamını içermektedir.

${ }_{\star \star \star}^{*}$ Doç. Dr., Sakarya Üniversitesi Eğitim Bilimleri Enstitüsü, Sakarya, hsaglam@sakarya.edu.tr

*** Öğrenci, Sakarya Üniversitesi Eğitim Bilimleri Enstitüsü, Sakarya.
} 


\section{GíRiş}

Toplumsal hayatın en küçük birimi olarak kabul edilen aile, toplumların kültür ve değerlerini geleceğe aktaran önemli sosyal kurumların başında gelmektedir. Hem neslin devamının sağlanabilmesi hem de sosyal yapının korunabilmesi aile yapısının sağlamlığı ve aile bireylerinin birbirleriyle olan iyi münasebetleriyle yakından ilişkilidir (Akbaş, 2008; Ekşi ve Katılmış, 2016). Aile, toplumun temel taşını oluşturan, evlilik ile kurulan bir birliktir. Toplum, aile denilen insan topluluğunun bir araya gelmesi ile oluşur (Könezoğlu, 2006). İnsan, evrensel bir sosyal kurum olan aile ocağında gözlerini dünyaya açar. illk gördüğü, tanıdığı ve ilişkilerini kurduğu kimseler anne, baba ve ailenin diğer fertleridir. İnsan ilk bilgilerini ve karakterinin özünü aile ocağından alır. Aile, ilk eğitim yuvasıdır. Çocuk, hayat kurallarını, sevgiyi, saygıyı, görgüyü, yardımlaşmayı, sevince ve kedere ortak olmayı ilk defa aile yuvasında öğrenir (Celkan, 1993; Kıncal, 1999; Çavdarcı, 2002). Aile, toplumun temeli, geleceğin güvencesi, değerlerin koruyucusu, en eski ve en güvenli sosyal kurumdur (Genç, 2016).

“Toplumun en küçük birimi olan aile, çocuğun etkileşimde bulunduğu, birçok şeyi gözlediği, taklit ederek öğrendiği, kişilik temellerinin atıldığı yerdir. Aile bireyleri arasındaki iletişim, etkileşim biçimi çocuğu etkilemekte, kişiliğini biçimlendirmektedir. Sevgi, saygı, yardımlaşma, dayanışma, hoşgörü, iletişim, sadakat gibi değerlerin çocuklara kazandırılmasında aile kurumunun önemli rolü bulunmaktadır. Çocuk, ailenin aynasıdır. Ailenin sahip olduğu özellikler çocuklarına da yansımaktadır" (Sağlam, 2008: 109). Aile, milleti millet yapan tüm değerlerin çocuğa kazandırıldığı kutsal mekânın adıdır. Şefkat, fazilet, merhamet, yardımseverlik ve acıma gibi insani duygular önce ailede teşekkül eder. Aile, aynı zamanda yabancılaşma ve dağılmaya set çeken bir kaledir. Milletin ve devletin bekası, ailenin kalıcı ve kucaklayıcı yapısı ile yakından ilgilidir. Aile aynı zamanda bir merhamet kurumudur (Tozlu, 2003). Aile, tarih boyunca her toplumda varlığını devam ettirmiş en önemli toplumsal kurumlardan birisidir (Aydın, 2000). Ailelerin bir araya gelmesiyle oluşan toplumun devamı ve bekası ailelerin devamı ve bekasıyla yakından ilişkilidir.

"Aile kurumu, üyelerini mutlu kılmak için üzerine düşen görevleri yapmak zorundadır. Bu görevleri yaparken sosyal değerleri, normları ve kurumları göz önünde bulundurma zorunluluğu vardır. Bunlar göz ardı edilirse bireyin gelecekteki hayatı olumsuz yönde etkilenir (Çavdarcı, 2002). Kurum olarak aile önemli olduğu için yaşaması, yaşatılması, ayakta tutulması gerekir. Aile, toplumun temelidir. Toplumun örgütlenmiş hali ise devlettir. Toplumun temelini oluşturan aile, aynı zamanda devletin de temelini oluşturmaktadır. Aile birliğine önem verme; bireye, topluma, toplumun örgütlenmiş hali olan devlete değer verme anlamına gelir. İnsan neye önem verirse onu yaşamında gösterir" (Sağlam, 2014: 366). "İnsanlar yaşadıkları çevrede kişi ve nesnelere kendileri için ifade ettiği anlam çerçevesinde önem ve değer verir. Önem verme aynı zamanda değer verme ile çok yakından bağlantılıdır. Aile, kişilerin önem ve değer verdiği unsurların en başında gelmektedir" (Başbakanlık Aile ve Sosyal Araştırmalar Genel Müdürlüğü [BASAGM], 2010: 305).

Sosyal değişmeye paralel olarak aile yapısında da değişme ve farklılaşmalar yaşanmaktadır. Eğitim seviyesinin yükselmesi, şehirleşme, değişim isteği, uygulanan kültürel, siyasî ve ekonomik politikalar aile yapısındaki değişimi etkileyen temel faktörlerdir (Çavdarcı, 2002). Ailedeki değişimle birlikte aileyi bir arada tutan bağlar incelmiş ve neredeyse kopma noktasına gelmiştir. Özellikle son çeyrek yüzyılda boşanma oranlarında hissedilir bir artış olmuştur. Bu durumun çözümü ailede değerlere önem vermekten geçecektir. Değerler, bir toplumun kültürünü diğer toplumların kültürlerinden ayıran ve millî sınırlar içindeki cemiyetin dağılmasını önleyen, pekiştirici ve kaynaştırıcı faktörlerdir. Değerler, sosyal ilişkilerin gelişmesinde ve kutuplaşmaların önlenmesinde aktif rol oynarlar. Toplumu birbirine kaynaştıracak birtakım standartlar bulunmadığında, fikirler arasındaki uzlaşmalar değerler tarafından sağlanır (İş̧̧i, 2013). Değerler, aileyi değerli kılan önemli yapı taşlarından biridir. Sosyal denetim mekanizmalarından en önemlisi olan değerler, toplumsal bütünlüğün ayrılmaz unsurlarındandır. Bireyin hayatında hemen her şey bu değerlere göre algılanır ve yaşamın anlamı bu şekilde öğrenilir (Güven, 1999). İnsan yaşamında böylesine önemli arz eden değer; belirli bir davranışın ya da herhangi bir şeyin tercih edilebilir ya 
da edilemez olduğu yönündeki inançtır (Rokeach, 1973). Değerler, toplumsal ve bireysel olarak kabul edilen güzellik, doğruluk, sevgi, dürüstlük ve sadakati tanımlar (Hastead ve Taylor, 1996). Bir başka ifadeyle bireylerin düşünce, tutum ve eylemlerinde birer standart olarak ortaya çıkan kültürel öğelerdir (Çağlar, 2005). Aile içindeki bireyler, özellikle anne ve baba, çocuğun ilk olarak model aldığı ve onları taklit ederek doğru davranışları öğrenmeye çalıştığı kişilerdir. Bireyin aile ve yakın çevredeki bireylerle olan etkileşimi değerlere ilişkin deneyimlerini artırmakta ve yaşamına yansıtılmasını sağlamaktadır. Değerlerin kazanılmasına ilişkin temeller bebeğin doğduğu andan itibaren ilk bulunduğu çevre olan ailede başladığı (Uyanık Balat ve Balaban Dağal, 2009) dikkate alındığında ailenin değerlerden uzak olması düşünülemez. Ailenin birliği ve devamı değerlere sıkı sıkıya bağlılığa dayanır. Özellikle ailede olmazsa olmaz değerlerin başında da sevgi, saygı, sadakat, sorumluluk ve hoşgörü gelmektedir. Öğretmenler de her çağda topluma örnek olmuş, yol göstermiş engin şahsiyetlerdir. Bu çalışma öğretmenlerin görüşleri ışığında aile birliğini korumada değerlerin rolünü belirlemek amacıyla yapılmıştır. Bunun için aile bireylerini birarada tutmanın sırrının ne olduğu, aile birliğini devam ettirmede sevginin, saygının, sadakatin, sorumluluğun ve hoşgörünün ne anlam ifade ettiği belirlenmeye çalışılmıştır.

\section{YÖNTEM}

$\mathrm{Bu}$ araştırma nitel paradigma desenlerinden biri olan olgubilim ile gercekleştirilmiştir. Olgubilim deseninde, yaygın uygulamaları ortaya çıkarmak ve katılımcılar tarafından oluşturulan anlamları tanımlamak ve açıklamak amaçlanmaktadır (Annells, 2006). Belli bir olguya ilişkin bireysel algıların veya perspektiflerin ortaya çıkarılmasının ve yorumlanmasının amaçlandığı çalışmalar genellikle olgubilim olarak tanımlanmaktadır (Yıldırım ve Şimşek, 2011). Bu araştırmanın odağını aile birliğini korumada değerlerin rolüne ilişkin olarak öğretmenlerin deneyimlerini nasıl anlamlandırdıkları oluşturmaktadır.

\section{1 Çalışma Grubu}

Çalışma grubu tipik durum örnekleme yoluyla seçilmiştir. Burada esas olan sıradışı olmayan ortalama, tipik bir durumun seçilmesidir. Araştırmada konuya ilişkin bilgisi olan kişilerle işbirliği yapılmış, ön bilgiler toplanmış ve sonunda (Büyüköztürk, Kılıç-Çakmak, Akgün, Karadeniz ve Demirel, 2014) aile birliğini korumada değerlerin rolü konu olarak belirlenmiştir. Araştırmanın çalışma grubunu 2014-2015 eğitim öğretim yılında Kocaeli ilinin Körfez ilçesinde görev yapan sınıf ve sosyal bilgiler öğretmenleri oluşturmaktadır.

Tablo 1. Araştırmaya Katılan Öğretmenlerin Kişisel Özellikleri

\begin{tabular}{llcc}
\hline Değişken & & $f$ & $\%$ \\
\hline Cinsiyet & Kadın & 24 & 68 \\
& Erkek & 11 & 32 \\
\hline Mesleki Kıdem & $1-10$ yıl & 21 & 60 \\
& $11-20$ yıl & 9 & 26 \\
& 21 yıl ve üstü & 5 & 14 \\
\hline Medeni Durum & Evli & 23 & 66 \\
& Bekâr & 12 & 34 \\
\hline Evlilerin Evlilik & $1-10$ yıl & 14 & 64 \\
Süresi & $11-20$ yıl & 5 & 23 \\
& 21 yıl ve üstü & 3 & 13 \\
\hline
\end{tabular}

Tablo 1'de görüldüğü gibi araştırmaya 24'ü (\%68) kadın, 11'i (\%32) erkek olmak üzere toplam 35 öğretmen katılmıştır. Araştırmaya katılan öğretmenlerinin \%60'ının 1-10 yıllık, \%26'sının 11-20 yıllık, \%14'ünün ise 21 yıl ve üstü kıdeme sahip olduğu görülmektedir. Araştırmaya katılan öğretmenlerin \%66'sının evli, \%34'ünün bekâr olduğu; evlilerin \%64'ünün 1-10 yıllık, \%23'ünün 1120 yıllık, \%13'ünün 21 yıl ve üstü evli oldukları görülmektedir. 


\subsection{Veri Toplama Aracı}

Araştırmacılar, sınıf ve sosyal bilgiler öğretmenleriyle aile birliğini korumada hangi değerlerin önemli olduğu konusunda görüşmeler yaparak görüşme formunun oluşması için ön çalışma yapmışlardır. Görüşme formunda yer alan sorular mülakatta öne çıkan değerleri yansıtacak şekilde oluşturulmuştur. Araştırmacılar tarafından hazırlanan görüşme formunda yer alan sorular öğretmenlerin aile birliğini korumada değerlerin rolüne ilişkin görüşlerini açığa çıkaracak şekilde yapılandırılmıştır. Görüşme formundaki soruların kapsam geçerliği için sınıf eğitimi, sosyal bilgiler eğitimi ve araştırma yöntemleri alanlarındaki üç uzmanın görüşüne başvurulmuş ve gelen öneriler doğrultusunda gerekli düzeltmeler yapılmıştır. Görüşme formunda; sizce, aile bireylerini bir arada tutmanın sırrı nedir (1), aile birliğini devam ettirmede sevgi ne anlam ifade eder (2), aile birliğini devam ettirmede saygı ne anlam ifade eder (3), aile birliğini devam ettirmede sadakat ne anlam ifade eder (4), aile birliğini devam ettirmede sorumluluk ne anlam ifade eder (5), aile birliğini devam ettirmede hoşgörü ne anlam ifade eder? (6) şeklindeki sorulara yer verilmiştir.

\subsection{Verilerin Analizi}

"Olgubilim araştırmalarında veri analizi, yaşamları ve anlamları ortaya çıkarmaya yöneliktir. Bu amaçla yapılan içerik analizinde verinin kavramsallaştırılması ve olguyu tanımlayabilecek temaların ortaya çıkarılması çabası vardır" (Yıldırım ve şimşek, 2011: 75). "içerik analizi belirli kurallara dayalı kodlamalarla bir metnin bazı kelimelerinin daha küçük içerik kategorileri ile özetlendiği sistematik, yinelelenebilir bir teknik olarak tanımlanmaktadır" (Büyüköztürk, Kılıç-Çakmak, Akgün, Karadeniz ve Demirel, 2014: 240). Öğretmenlerden elde edilen veriler içerik analizine tabi tutularak çözümlenmiştir. "Bu amaçla toplanan verilerin önce kavramsallaştırılması, daha sonra da ortaya çıkan kavramlara göre mantıklı bir biçimde düzenlenmesi ve buna göre veriyi açıklayan temaların saptanması gerekmektedir" (Yıldırım ve Şimşek, 2013: 259). "Kodlardan yola çıkarak verileri, genel düzeyde açıklayabilen ve kodları belirli kategoriler altında toplayabilen temaların bulunması gerekmektedir. Temaların bulunması için önce kodlar bir araya getirilir ve incelenir. Kodlar arasındaki ortak yönler bulunmaya çalışılır. Tematik kodlama için ilk aşamada, ortaya çıkan kodların benzerlik ve farklııkırının saptanması ve buna göre birbiriyle ilişkili olan kodları bir araya getirebilecek türden temaların belirlenmesi gerekir" (Yıldırım ve Şimşek, 2013: 268). Kodlamalar arasındaki tutarlılık .91 olarak tespit edilmiştir. Araştırmada sonuçlar rapor edilirken doğrudan alıntılara yer verilmiştir. Temalara ve kodlara yönelik sınıf öğretmenlerinden birebir alıntılar yapılarak geçerlilik sağlanmıştır (Patton, 1997). Alıntıların aktarılmasında öğretmenlere 1'den 35'e kadar kod numarası verilmiştir.

\section{BULGULAR}

Bu bölümde sınıf öğretmenlerinin görüşlerinden doğrudan alıntılar yapılmış, belirlenen temalara ve elde edilen kodlara yer verilmiştir.

Tablo 2. Öğretmenlerin Aile Bireylerini Bir Arada Tutan Sırra İlişkin Görüşleri

\begin{tabular}{llc}
\hline Temalar & Kodlar & $\mathrm{n}$ \\
\hline Değerler & Sevgi & 28 \\
& Saygı & 26 \\
& Sabır & 1 \\
& Sadakat & 5 \\
& Sorumluluk & 3 \\
& Hoşgörü & 11 \\
& Fedakârlık & 6 \\
\hline Beceriler & Karar verme & 3 \\
& iletişim & 2 \\
& Empati & 2 \\
\hline
\end{tabular}


Tablo 2'de, araştırmaya katılan öğretmenlerin aile bireylerini bir arada tutan sırra ilişkin görüşlerinin "değerler" ve "beceriler" temaları altında incelenmesi mümkündür. Öğretmenlerin değerler temasına ilişkin görüşlerine; "Karşıııklı sevgi, sadakat, her zorluğun üstesinden gelir [K1]." "Aile bireylerini bir arada tutmanın sırrı karşıııklı anlayış, hoşgörü, samimiyet ve sevgidir [K2]." "Birbirlerinin yaşam alanlarına, özgürlüklerine, ilgilerine ve farklılıklarına saygı duymak, birbirlerini kendi doğrularıyla boğmamaktır [K4]." "Aile bireylerini bir arada tutmanın sırrı 4S kuralıdır. Bu da sevgi, saygı, sabır ve sadakattir [K5]." "Karşılıklı sevgi, saygı, güven, hoşgörü, fedakârlık, dayanışma [K8]." "Sevgi, saygı, hoşgörü, fedakârlık [K10]." "Eşler arasındaki sevgi, saygı, hoşgörü evliliğin devamını sağlar [K11]." "Saygı, güven, sevgi, paylaşım [K13]." "Sevgi, saygı, hoşgörü, sadakat [K16]." "Önce hoşgörü gerekir [K17]." "Sevgi, saygı ve bağlılıktır [K20]." "Saygı, sevgi, hoşgörü [K21]." "insanların karşısındakinin mutluluğuna önem vermesi, birbirlerini sevmeleri, saygı duymaları ve anlayışlı olmaları aileyi bir arada tutar [K22]." "Sevgi, saygı, fedakârlık [K23]." "Saygı, sevgi, hoşgörü, ilgi ve alaka, paylaşım alanlarının ortak olması aile bireylerini bir arada tutar [K24]." "Aile bireylerini bir arada tutmanın sırrı sevgi, saygı, hoşgörüdür [K25]." "Bireylere gelişimlerinin ilk anından itibaren sevgi vererek birlikte var olduklarının bilincini aşılamak, fedakârlık ve sabır bilinci verebilmektir [K26]." "Birbirlerine karşı anlayışlı olmalılar. Birbirlerini dinlemeliler. Sevgi, saygı çevresinde birbirlerine yaklaşmalılar [K27]." "Saygı ve anlayış [K28]." "Karşılıklı sevgi, saygı ve güvendir [K29]." "Karşılıklı güven, anlayış, sevgi, saygı [K30]." "Karşılıklı sevgi ve saygı [K31]." "Saygı, sevgi, hoşgörü [K32]." "Karşılıklı sevgi, saygı, anlayış [K33]." "Önce saygı ve sonra onlara karşı duyulan karşılıksız sevgi [K34]." ifadeleri örnek olarak verilebilir.

Öğretmenlerin aile bireylerini bir arada tutan sırra ilişkin beceriler temasına ilişkin görüşlerine; "Olumlu iletişim ve bir arada bulunma isteğidir [K6]." Iletişim olursa bu özelliklerin hepsi gerçekleşir [K8]." "En önemli faktörün iyi bir evlilik yapmak olduğunu düşünüyorum. Uyumlu ve anlaşan çiftler ailesini bir arada tutma konusunda daha başarılı olacaklardır [K9]." "Evliliğin başında ailelerin sosyoekonomik durumlarının eşitliği, daha sonraki yıllarda sabır ve özveri gerekiyor [K12]." "Kişiler varlık amaçlarının bilincinde olmalı ve dünyaya karşı cins doğumlu olarak da gelebileceğini bilmelidir [K14]." "Doğru kişiyle yaptığınız evlilikle ömür boyu mutlu olursunuz [K29]." ifadeleri örnek olarak verilebilir.

Tablo 3. Öğretmenlerin Aile Birliğini Devam Ettirmede Sevginin Gücüne İlişkin Görüşleri

\begin{tabular}{llc}
\hline Temalar & Kodlar & $\mathrm{n}$ \\
\hline Sevgi göstergeleri & Tahammül etme & 4 \\
& Zorluklara katlanma & 3 \\
& Karşlık beklememek & 3 \\
\hline Sevginin gücü & Ailenin harcı & 18 \\
& Eviliăgi devam ettiren güç & 8 \\
& Güven ve huzur & 4 \\
\hline
\end{tabular}

Tablo 3'te, araştırmaya katılan öğretmenlerin aile birliğini devam ettirmede sevginin gücüne ilişkin görüşlerinin "sevgi göstergeleri" ve "sevginin gücü" temaları altında incelenmesi mümkündür. Öğretmenlerin sevgi göstergeleri temasına ilişkin görüşlerine; "Sevgi olmazsa insanların birbirine tahammül etmesi zorlaşabilir. Seven, gerçek anlamda sevgi hisseden bireyler arasında anlaşmazlıklar, sorunlar daha kolay çözülür. Seven insan bazı durumları görmezden gelir [K2]." "Sevgi olmazsa kişiler birbirine katlanamaz [K10]." "Sevgi insanların birbirine tahammülünü arttırır. $\mathrm{Bu}$ da beraber yaşamak konusunda ortaya çıkması muhtemel sorunların telafisini kolaylaştırır [K19]." "Evlilik hayatında karşılaşılan zorluklarda sevgi hep kolaylaştırııı etken olur [K23]." "Sevginin rolü vardır. Hatta en önemlisi olduğunu düşünüyorum. Sevmediğiniz birinin kötü, alışık olmadığınız tavırlarına tahammül gösteremezsiniz doğal olarak [K25]." "Aile birliği için bence en önemli sevgidir. Sevdiğiniz bir insanla beraberseniz her sıkıntıya, her zorluğa katlanırsınız. Sevmediğin ya da az sevdiğin biri ise birliktelik uzun süreli olmaz. Bir yerde biter [K29]." ifadeleri örnek olarak verilebilir. 
Öğretmenlerin sevginin gücü temasına ilişkin görüşlerine; "Sevgi aileyi bir arada tutan çimentodur [K3]." "Sevgi; aileyi birleştirir. Birbirine bağlar. Güven ve huzur duygusunun kaynağıdır [K4]." "Aile birliğini devam ettirmede en büyük rol sevgidir. Aile birliğinin temeli sevgi ile atılır. Eğer ailede sevgi varsa saygı, sadakat, hoşgörü de olur [K5]." "Sevgi kavramı soyut olduğundan bunun belirtileri davranış ve düşüncelerde gösterilir bence. Onun varlığıyla kendini mutlu hissetmektir [K6]." "Sevgi olmadan birlik olmaz. Sevgi ile atılan her adım, yapılan her davranış anlamlıdır [K7]." "Aile birliğini devam ettirmek için sevgi başrolü oynar. Aralarında sevgi bağı bulunmayan bir aile hayatı cehennemden farksızdır [K8]." "Sevgi bana göre ailenin mayası, tutkalıdır. İnsan zaten sevdiği her varlığı sürekli yanında ister, bırakmaz. [K9]" "Sevgi kabullenmektir, her şeyi ile benimsemek ve ona ayak uydurabilmede en büyük destektir [K13]." "Sevdiğimiz şey bizim için değerlidir. Ailemizi bir ömür boyu severiz. Koşulsuz, şartsız [K15]." "iç̧inde sevgi olan kişi, karşısındakinin kusurlarını da yeri geldiği zaman görmemezlikten gelir [K16]." "Sevgi her şeyin temelidir. Insan sevdiği kişilerin birçok olumsuz davranışını görmezden gelebilir [K17]." "Aile birliğinin temeli sevgiye dayanır. Temel sağlam değilse o birliğin kalıcı olması mümkün değildir [K18]." "Sevgi insanların arasındaki en kuvvetli bağdır [K20]." "Sevginin olduğu bir ortam insanları içine çeker. Aile bireyleri de sevginin olduğu ortamda daha çok bir araya gelip vakit geçirmek ister [K21]." "Sevgi olmazsa bir ömür boyu birlikte olmak mümkün değildir [K24]." "Baştan sona, sevginin olmadığı, etkin olmadığı hiçbir nokta yoktur. Ailenin mayası, aşısı, harcı hep sevgidir [K26]." "Sevgi kişilerin aile olma yolunda adım atmalarını sağlayan ilk duygudur. Sevgi birliği sürdürmede ve daha da güçlendirmede temeldir [K27]." "Sevildiğini hissetmek kişiye kendini değerli hissettirir. Bu da insanı mutlu eder [K33]." "Sevgi benim için karşılığı olmayan duygudur. Bu sevgide ise hiçbir zaman karşılık beklenmez [K34]." "Sevgisiz bir ortamda birliğin olması çok zordur [K31]." "Bence sevmeden bir evlilik yürütülemez [K35]." ifadeleri örnek olarak verilebilir.

Tablo 4. Öğretmenlerin Aile Birliğini Devam Ettirmede Saygının Gücüne Illişkin Görüşleri

\begin{tabular}{|c|c|c|}
\hline Temalar & Kodlar & $\mathrm{n}$ \\
\hline \multirow[t]{2}{*}{ Anlayış } & Dinleme & 2 \\
\hline & Değer verme & 2 \\
\hline \multirow[t]{4}{*}{ Saygının gücü } & Saygı önemlidir & 12 \\
\hline & Sevgi ve saygı eşit önemdedir & 6 \\
\hline & Sevgiden sonra gelir & 3 \\
\hline & Fikirlere saygı & 1 \\
\hline \multirow[t]{2}{*}{ Saygının boyutları } & Karşılıklı saygı & 5 \\
\hline & Birbirlerinin sınırlarına saygı & 2 \\
\hline
\end{tabular}

Tablo 4'te, araştırmaya katılan öğretmenlerin aile birliğini devam ettirmede saygının gücüne ilişkin görüşlerinin "anlayış" "saygının gücü" ve "saygının boyutları" temaları altında incelenmesi mümkündür. Öğretmenlerin anlayış temasına ilişkin görüşlerine; "Saygı duymak bireylerin birbirlerine olan sevgilerinin yanında en olmazsa olmazdır. Çünkü bazı durumlarda saygı beraberinde sevgiyi getirir. Aile bireyleri birbirlerine saygı duyduğu ölçüde problemlerini daha kolay çözerler. Birbirlerine saygı duydukları için her durumda birbirlerini dinlerler, sorunlar büyümeden, gizli saklı olmadan her şey karşılıklı istişare ile kolaylıkla çözülür [K2]." "Saygı biterse değer vermede biter. Eşler arasında her iki tarafında birbirine değer vermesi gerekir. Sevgi, saygı ve sabır karşıııkı olmalıdır [K12]." "Aile bireyleri ne kadar aynı ailenin üyesi olsa da hepsinin karakteri, olaylara bakış açısı farklı, olaylara verdiği tepki farklıdır. Herkesin birbirini dinleyip, düşüncelerine saygılı olduğu sürece aile bireyleri aynı sevgi değil dolu bir ortamda olduğu gibi, bir çekim oluşup bir arada bulunmaktan mutluluk duyarlar [K21]." "Saygı bireylerin kendilerini değerli hissetmelerini sağlar [K30]." ifadeleri örnek olarak verilebilir.

Öğretmenlerin saygının gücü temasına ilişkin görüşlerine; “Hakların ve sorumlulukların adil olarak paylaşımının sağlandığı aile ortamında "ötekileşme" değil "özdeşleşme" meydana gelir. Bunu sağlayan en önemli etken saygıdır [K3]." "Saygı, sevginin devamlı olmasını sağlar. Saygı sevgiden 
daha önemlidir [K4]." "Aile birliğini devam ettirmede sevgiden sonra en büyük rol saygınındır. Sevgi aile birliğinin temeli ise saygı da duvarları oluşturur. Aile birliğinin uzun sürmesi, sağlam olması saygıya bağlıdır [K5]." "Saygı olmadan insanlar birbirlerine tahammül edemez ve sorunlar yaşarlar [K7]." "Saygı var olan sevginin zarar görmesini engelleyecektir [K9]." "Saygının olmadığı yerde sevgi olmaz. Saygı ve sevgi aile birliğinin sağlayan unsurlarındandır [K10]." "Saygı sevgiyi besler. Saygısızlık sevginin tükenmesine neden olur [K11]." "Saygı bağlılığı daha da arttırır [K15]." "Ama sevgi ile saygı birlikte olan kavramlardır. Sevgide zorunluluk yoktur ama saygı da zorunluluk vardır. Sevmediğimiz birine saygı göstermek zorundayız. Lakin bunu aile içinde düşünecek olursak, aile içinde her ikisinin de birlikte olması gerekir [K16]." "Saygının olmadığı bir aile güçsüzdür. Tutunacak bir şeyi olmaz. Öyle bir ailede iletişim kurulamaz [K24]." "Saygı, özellikle yaşanan sıkıntılar ve sorunların ifade edilmesinde devreye giriyor bence. Saygılı bir tutum içinde olmak, kendini ifade ederken kullandığın kelimelere, kurduğun cümlelere dikkat etmek gerekiyor. Sevgi ve saygı birleşmeli. İisi bir arada olursa, çözülemeyecek hiçbir sorun olmayacağını düşünüyorum [K25]." "Saygı kişilerin de birbirlerine karşı olmazsa olmazıdır. Kişiler birbirlerine saygıyla yaklaşmazlarsa aile birliğinden söz edilemez [K27]." "Sevgi, saygıyı beraberinde getirir. Sevdiğimiz için eşimizin ailesine, arkadaşlarına saygı duyarız [K29]." "Saygının eksik olduğu bir ailede birliğin kurulması olanaksızdır [K31]." "Saygı, bireylerin birbirleri arasındaki ilişkinin temelini oluşturur [K32]." "Saygı bence sevgiden daha önemlidir. Saygısızlık olmadığı sürece sevgi her zaman vardır [K34]." "Aile bireylerinin kendi seçimlerini yapmasına saygı göstermek aile birliğinin devamında önem taşır [K33]." "Kişiyi seversin ama saygın yoksa sevgin de biter [K35]." ifadeleri örnek olarak verilebilir.

Öğretmenlerin saygının boyutları temasına ilişkin görüşlerine; "Eşler birbirine saygı göstermezse evlilik temeli çürümeye başlayan bir ahşap eve benzer. Saygı olmayan bir birlikte eşler birbirine anlayışsız davranır ve birliktelik devam edemez [K1]." "Ailede saygı, kendi düşüncelerinin yanı sıra karşı tarafında düşüncelerine önem vermektir. Saygı gösterilmeme durumunda eşler birbirini incitip rencide edebileceğinden küskünlük, bireysel yaşama isteği ve iletişiminden kaçınma söz konusu olacağından aile birliği bozulmaktadır [K6]." "Saygı aile birliği sağlamada önemli bir etkendir. Aile üyeleri birbirine saygılı davranırsa yetiştirdiği nesiller de topluma saygılı olur [K8]." "Kişi saygı gösterdiği kadar saygı göreceğini bilerek hareket etmelidir. Insanın fıtri intiyaçları, yeterlilikleri göz önüne alınarak ona bir bütün halinde bakılmalı varlığını olduğu gibi kabul etmeli ve her daim saygı gösterilmelidir. Saygı olduğu sürece eksiklikler düzeltilerek aile birliği devamı sağlanarak gelişir [K14]." "Sevgiden sonra en önemli şey saygıdır. Bazen sevgi bitebilir ancak saygının hiçbir zaman bitmemesi gerekir. Saygı her şeyin temelidir. Ancak saygıda karşılıklı olmalıdır. Hep aynı taraftan saygı beklenmemelidir. Aksi takdirde bu saygı değil de biraz duygu sömürüsü olur [K17]." "Tarafların birbirlerinin kişiliğine ve birey olarak yaşadıklarına saygı göstermesinin "biz" olmak yolunda "ben"i korumanın şart olduğunu düşünüyorum [K19]." "Karşıııklı saygı olmalı. Aile bireyleri birbirlerine her konuda saygı göstermeli [K22]." "Önce kişilerin kendisine saygı duymasını öğrenmeleri gerekir. Ardından beraberliklerini sürdürebilmek için birbirlerinin sınırlarına saygı göstermeleri gerekir. Bu durumda daha düşünceli ve hassas davranışlar ile saygı açığa çıkar. Sonucunda da birbirini düşünen, hassasiyetlerine saygı gösteren, birbirini koruyan bireyler meydana gelir [K26]." ifadeleri örnek olarak verilebilir.

Tablo 5. Öğretmenlerin Aile Birliğini Devam Ettirmede Sadakatin Gücüne Illişkin Görüşleri

\begin{tabular}{llc}
\hline Temalar & Kodlar & $\mathrm{n}$ \\
\hline Gönülden bağlıık & Güven & 12 \\
& Şeffaflık & 3 \\
& Bağlıık & 11
\end{tabular}

Tablo 5'te, araştırmaya katılan öğretmenlerin aile birliğini devam ettirmede sadakatin gücüne ilişkin görüşlerinin "gönülden bağlılık" teması altında incelenmesi mümkündür. Öğretmenlerin gönülden bağlıık temasına ilişkin görüşlerine; "Nikâh memurunun önünde eşlerin birbirine söylediği iyi günde, kötü günde şeklinde başlayan o karşılıklı sözün çerçevesidir [K1]." "Güvenmek, 
vefa duygusu insana mutluluk, yaşama sevinci verir [K2]." "Sadece fiziki olarak aldatma değil veya aldatılma değil, ruhen bile insanın eşine bağlı olması düşüncelerinde de sadık olması kanaatindeyim [K3]." "Eşlerin birbirlerine olan bağlıı̆̆ını gösterir. Eşler arasında sadakat varsa aile birliği daha sağlam olur [K5]." "Sadakat bende güveni çağrıştırıyor. Insanlar kendilerini güvende oldukları bir ortamda ya da kişilerin yanında olmak ister [K6]." "Sadakat insanlara güven veren bir duygudur. Güvense bütün duyguların oluşabilmesi için bir zemin görevi görür. Güven yoksa sevgi de saygı da oluşamaz [K7]." "Ailenin ortak değerlerine bireyler bağı kalmalı, birbirlerine destek olmalı, aile içinde kalması gereken olaylar dışarıya yansıtılmamalı [K8]." “Evliliğin neslin devamı için yapıldığı düşünüldüğünde sadakatin de bu doğrultuda tüm aile fertleri için meşru zeminde değerlendirilmesi gerekmektedir [K14]." "Ailede güven ve sadakat varsa aile birliği o kadar güçlüdür [K15]." "Sadakatsizliğin başladığı anda aile birliği bozulmuş sayılır [K16]." "Aile bireyleri birbirlerine sadakatle bağlı olmalıdır. Sadakatten şüphe edildiği an ne hoşgörü kalır ne de saygı [K17]." "Sadakat ya da bağlılı: Bu kavram çok önemli bir unsurdur. illgi, dikkat başka yönlere kaymamalı. Aksi halde önemli sorunlar baş gösterir [K18]." "Eşler arasındaki sadakat; sevgi, saygı, hoşgörü gibi değerlerin olmasının temelidir. Tabi bu arada eşler arasında sadakat konusunda bir cinsiyet ayrımı yoktur [K20]." "Bir yuvada bir çekim gücünün oluşup aile bireylerini kendine çekmesinde nasıl ki sevgi ve saygının güçlü bir önemi varsa sadakatte bu rolde önemli bir ayaktır. İnsanlar birbirine bağlı olduğu sürece birbirlerine güvenleri tam olur [K21]." "Sadakat, güven bize bağlılığı gerektiriyor [K25]." "Sadakat aile olma sürecinde sevgi ve saygının oluşmasında ön koşuldur. Sadakat güven için temeldir [K27]." "Düzgün bir insan için sadakat önemlidir. Hiçbir şekilde sadakatsizlik yapılmamalıdır. Çünkü affedilmez [K29]." "Aile birliği için, birbirine güven çok önemli bir unsurdur. Kişilerin birbirine güven duyması sadakatten geçer [K31]." "Sadakat sürekliliğini koruduğunda bireyler arasındaki güven duygusunun da sürekliliği sağlanır [K32]." "Güven duygusunun sarsılmazlığını ifade eder [K33]." "Evliliğin devamı için sadakat gereklidir [K34]." "Sadakat, saygının ve sevginin getirisi olarak düşünüyorum. Sevmeyen ve saygısı olmayan kişilerden sadakat beklenmez [K35]." ifadeleri örnek olarak verilebilir.

Tablo 6. Öğretmenlerin Aile Birliğini Devam Ettirmede Sorumluluğun Gücüne Illişkin Görüşleri

\begin{tabular}{llc}
\hline Temalar & Kodlar & $\mathrm{n}$ \\
\hline İşbölümü & Bireysel sorumluluk & 19 \\
& Karşılıklı sorumluluk & 7 \\
& Cinsiyete dayalı sorumluluk & 4 \\
\hline
\end{tabular}

Tablo 6'da, araştırmaya katılan öğretmenlerin aile birliğini devam ettirmede sorumluluğun gücüne ilişkin görüşlerinin "işbölümü" teması altında incelenmesi mümkündür. Öğretmenlerin işbölümü temasına ilişkin görüşlerine; "Sorumluluk aile birlikteliğine ölümsüzlük iksiri görevindedir [K1]." "Her şeyi tek bir insanın yapamayacağını düşünerek bireyler evde, dışarıda her nerede olurlar ise aile olmanın onlara yüklediği sorumlulukları yerine getirmek durumundadırlar [K2]." "Aileyi meydana getiren her fert, kendi kapısının önünü temizlerse sorun kalmaz. Her aile üyesi gücü ve imkânı ölçüsünde sorumluluğu yerine getirmeli [K3]." "Sorumluluk, bireysel olarak üstlenmem gereken eylem ya da düşüncedir. Ailedeki tüm bireylerin cinsiyet, konum gereği farklı sorumlulukları vardır. Ailede birlik ve sorumluluk kavramları yan yana getirildiğinde bir makine, mekanizmayla eşleştirirsek her parça, her madde görevini tam yerine getirirse işlem sorunsuz tamamlanır. Ailede de bu böyledir [K6]." "Kişinin hem kendine karşı hem de yaşadığı insanlara karşı belli sorumlulukları vardır. Herkes kendi sorumluluklarının farkında olursa birbirini rahatsız etmeden mutlu bir yaşam sürdürebilir [K7]." "Ailede görev paylaşımı, tüm bireylerin sorumluluk sahibi olması, kendine düşen görevleri aksatmadan yerine getirmesi gerekir [K8]." "Sorumluluk aile ortamında paylaşmayı, yükün dağıımını sağlayacaktır. Bu sayede kırgınlık ve tartışmaların önüne geçilecektir [K9]." "Eşler arasındaki sevgi ve saygı karşılıklı sorumlulukların bilinmesini sağlar [K11]." "Evliliğe karar verdiğiniz zaman en büyük sorumluluğa girmişsiniz demektir. Sorumluluk o evlilikte omuzlarınıza binen en önemli yüktür [K12]." "Sorumluluğu ortak paylaştıkça, herkes aile içinde görevini bilip düzgün yaptıkça aile devamlıl̆ı̆ sağlanabilir [K13]." "Sorumluluk 
paylaşımı genellikle güçlü olanın, erkeğin, paylaştırması ve güçsüz olanın fazla sorumlulukla ezilmesi neticesinde sonuçlanmaktadır. Tam tersine güçlü olanın daha çok sorumluluk alması ve her zaman için her tür problemi göğüsleyici olması gerekmektedir [K14]." "Geleneksel Türk toplumunda ailedeki sorumluluğun çoğunu ne yazık ki üstlenen bayan olmaktadır [K16]." "Ailede her ferdin kendi üzerine düşen görev ve sorumluluğu yerine getirmesi gerekir. Ailede iş bölümü yapılmalı ve herkes kendi işini mükemmel bir şekilde yapmalıdır. Aksi takdirde eleştiri ve geçimsizliğin ilk temelleri atılır [K17]." "Sorumluluklar paylaşılması gereken en önemli unsurlar. Ev, iş, sosyal hayat her biri paylaşılması gereken alanlardır. Bunlarda da toplumsal cinsiyet rollerine bağııı̆̆ın derecesi etkili bir faktördür bence. "Kadın yapmaz, erkek yapmaz" konusundaki esneklik uyumu da beraberinde getirecektir [K19]." "Sorumluluk aile içinde değişkenlik gösterilebilir, ancak gerektiğinde konuşmadan bile anlaşılabilecek bir olgu olduğu sürece olumlu gelişim gösterir. Ancak yerine getirilmediğinde önce saygı, sonra da sevgiyi yer bitirir [K20]." "Aile bireylerinden herkes üzerine düşen görevi yaparsa yine bir güven ortamı oluşacağından bu da aile içindeki çekim kuvvetini arttırır [K21]." "Herkes üzerine düşen sorumluluğu yerine getirmenin yanı sıra diğerine de destek olmaya gayret etmeli [K22]." "Kişinin tüm sorumluluklarının ve evlilik hayatındaki sorumlulukların bilincinde olması gerekir [K23]." "Aile üyelerinin her birinin bir diğerine karşı sorumlulukları vardır. Her birey bunların farkında olup davranışlarını buna göre şekillendirmelidir [K25]." "Aile birbirini tamamlayan bir organın dokuları gibidir, hepsinin birlikte çalışması gerekir [K26]." "Sorumluluklar aile içinde karşılıklı olmalıdır. Eşler birbirlerine sorumluluklar konusunda destek olmalıdır. Sorumlulukları gerçekleştirme konusunda ise iyi niyetli olmalıdırlar [K27]." "Evde herkes üzerine düşen sorumluluğu yerine getirirse ortam huzurlu olur. Sadece bir kişinin işleri yapması, çocukla ilgilenmesi yorucudur. Paylaşım yapılarak ve bireyler üzerindeki işleri düzenli yaparak mutluluk sağlanır [K29]." "Evlilik sorumluluk getiren bir kurum [K35]." ifadeleri örnek olarak verilebilir.

Tablo 7. Öğretmenlerin Aile Birliğini Devam Ettirmede Hoşgörünün Gücüne Illişkin Görüşleri

\begin{tabular}{llc}
\hline Temalar & Kodlar & $\mathrm{n}$ \\
\hline Hoşgörü Belirtileri & Sabır gösterme & 2 \\
& Farklılıklara Saygı & 12 \\
& Kusurları görmezden gelme & 6 \\
\hline Hoşgörünün Temeli & Karşlıklı olmalı & 3 \\
& Sorumlu davranmak & 5 \\
& Sınırları var & 2 \\
\hline
\end{tabular}

Tablo 7'de, araştırmaya katılan öğretmenlerin aile birliğini devam ettirmede hoşgörünün gücüne ilişkin görüşlerinin "hoşgörü belirtileri" ve "hoşgörünün temeli" temaları altında incelenmesi mümkündür. Öğretmenlerin hoşgörü belirtileri temasına ilişkin görüşlerine; "Hoşgörü olmadığı takdirde sabır göstermek zorlaşır. Mutlaka aile birbirlerine hoşgörülü olmak zorundadır. Aksi takdirde mutlu olmak çok zor. Çiftler birebir aynı olamayacağı için farklııkları zenginlik olarak görerek hoşgörü göstermelidirler [K2]." "Hoşgörü saygının devamı ve beraberidir. Karşı tarafın sözlerine ve davranışlarına saygı duymak, hoş görmektir. Hoşgörü yoksa karşılıklı birbirini kırmak, bağırmak varsa birlik olmaz [K6]." "Aile üyelerinin hoşumuza gitmeyen bazı davranışlarında hoşgörülü olmak, sevgiyle sorunları çözümlemek, öfkelenmeden, kavga etmeden sorunlara hoşgörüyle çözüm bulmak birliğin sağlanması açısından önemlidir [K8]." "Hoşgörü, tüm olumsuzlukların üzerine, beyaz, saf, temiz bir örtü örtmek gibidir. Zaten seven kişi, gerçekten yüreği ile severse, hoşgörüsüz olamaz. Saf ve gerçek sevgi, saygıyı, birlikteliği, hoşgörüyü, mutlu bir yuvayı ortaya çıkaracaktır [K9]." "Hoşgörü tek taraflı yürümez bir yerde tıkanır. Eşler arasında karşılıklı olmalıdır [K10]." "Her bireyin birbirinden farklı olduğu gerçeği hoşgörüyü önemli kılmaktadır. Günümüzde yöresel, bölgesel hatta ırksal ve ülkesel farklılıkların yaşandığı evlilikler yaygınlaşmaktadır. Aile kültürünün bu kadar farklı olduğu ortamlarda büyümüş insanların kurduğu ailelerin tutkalı hoşgörü olacaktır [K19]." "Hoşgörü sevgi ve saygıyı besleyen, 
kuvvetlendiren bir etkiye sahiptir [K20]." "Hepimiz farklıyı. Bir ailenin farklı üyeleri olarak birbirimizin farklılıklarını kabul etmemizin, bunu bir güzellik olarak görmemizin sırrıdır hoşgörü [K25]." "Aile birliği içerisinde bireylerin kendi zamanlarını yaşadıklarını kabul etmeliyiz, arada kuşak çatışması, düşünce farklııkları, hayata yöneliş durumları farklı olabilir. Bireylerin birbirinin kişilik özelliklerinin farklılıklarının birbirleriyle yaşantılarını devam ettirmelerine engel olmaması gerekir. Bu da elbette hoşgörüyle mümkündür [K26]." "Eşinizin ufak tefek yanlışlıkları olabilir, hataları olabilir. Ama seviyorsanız hoş görürsünüz ve öyle de yapmalısınız. Hataları örtmek, affetmek en güzelidir [K29]." "Aile içindeki farklı görüşlere, hatalara hoşgörülü olmak gerekir [K31]." "Eksikleri, hataları görmezden gelmeyi, anlayışlı olmayı bilmektir [K33]." ifadeleri örnek olarak verilebilir.

Öğretmenlerin hoşgörünün temeli temasına ilişkin görüşlerine; “Hoşgörü toplumları, cemiyetleri medeniyet yapan en üstün kavram. Yalnız aile bireylerinden biri birliktelik, iyi niyet uğruna bazı hallerinden feda ederek yola devam kararında ısrar ederken, diğer bireyler bu durumdan kar etmemeli iyi niyet ortak olmalı [K3]." "Karşılıklı hoşgörünün önemli olduğunu düşünüyorum. Tek taraflı hoşgörü bence bacağı kırık sandalye gibidir. Güvenip de üstüne ağırlık veremezsin [K4]." "Aile birliğinin huzur ve mutlulukla sürmesinde aile bireylerinin birbirlerine hoşgörü ile davranmaları önemlidir. Hoşgörünün olmadığı ailelerde huzursuzluklar, tartışmalar, kavgalar eksik olmaz [K5]." "Eşlerin birbirine hoşgörülü ve anlayışıı olması sevgi bağlarını arttııır. Tüm değerler birbiriyle bağlantılı. Sağlıklı bir evlilik için eşler arsında bütün değerler olmalıdır. Birinin eksikliği diğerinde sorunlara yol açar [K11]." "Insanın beşer olduğu ve her an hatalar yapma potansiyeline sahip olduğu düşünüldüğünde her alanda olduğu gibi ailede de hoşgörü kaçınılmazdır. Ancak hoşgörüyü olumsuz ve zedeleyici davranışları görmezden gelmek gibi düşünmeyip, bu davranışların değişimi için etkin çalışmalar yapılmalıdır [K14]." "Hoş görülecek duruma göre değişir. Bazı durumların hoşgörüsü olmaz [K16]." "Hoşgörü de belli bir oranda makul görülebilir. Her şey hoş görülemez. Sorgulanması gereken davranışlar olabilir. Medeni insanlar gibi karşılıklı oturup sorunlar değerlendirilir, ortak bir noktada buluşulur [K18]." "Hoşgörü her alanda olmalı ancak insanlar karşısındakinin hoşgörüsüne sığınmamalı [K22]." "Ailedeki herkesin hoşgörülü olması sağlıkı bir aile ortamı oluşturur [K24]." "Uzun süre bir evlilik yürütebilmek için hoşgörülü olmak gerekir. Kavgasız bir evlilik istiyorsak hoşgörülü insanlar gerektirir [K35]." ifadeleri örnek olarak verilebilir.

\section{SONUÇ, TARTIŞMA VE ÖNERILER}

Aile birliğini korumada değerlerin rolünü belirlemek amacıyla yapılan bu araştırmada aileyi bir arada tutmanın sırının değer olarak saygı, sevgi, sabır, sadakat, sorumluluk, hoşgörü ve fedakârlıkta; beceri olarak karar verme, iletişim ve empatide olduğu sonucuna ulaşıımıştır. İlköğretim Sosyal Bilgiler Programı'nda yer alan, öğrencilere kazandırılması amaçlanan değer ve becerilerin (Milli Ĕgitim Bakanlığı [MEB], (2005) aile birliğini korumada önemli olduğunun öğretmenler tarafından da vurgulanmış olması önemli bulunmuştur. Ayrıca aile birliğini korumada; sevgi, saygı, sadakat, sorumluluk ve hoşgörü değerlerinin çok önemli rol oynadığı tespit edilmiştir. Bu durum BASAGM (2010) tarafından yapılan çalışmada, katılımcıların bir bütün olarak ailelerine $\% 99.3$ oranında önem verdikleri, Türk toplumunda aile kurumunun çok önemli görüldüğü sonucuyla benzerlik göstemekte, kendisi de bir değer olan aile, değerler alanının merkezine oturttukları yönündeki araştırma sonuçlarıyla da örtüşmektedir. Söz konusu araştırmada katılımcılar; "maddi ve manevi sorunlar olduğunda başvurulması gereken ilk yer ailedir" ve "ailemin iyiliği için her türlü sıkıntıya katlanabilirim" ifadelerine yüksek oranda katılım göstererek aileye verilen önemi ortaya koymuşlardır. Ayrıca Sağlam'ın (2014) ilköğretim öğrencilerinin aile birliğini önemseme düzeylerini belirlemeye yönelik olarak yaptığı araştırma sonuçlarıyla da örtüşmektedir. Benzer şekilde Şener ve Terzioğlu (2002) yaptıkları araştırmada, eşler arasında duygu ve düşüncelerin paylaşımının artması ile gerek kadın, gerek erkeklerin evlilik uyum puanlarının anlamlı bir şekilde arttığını saptamışlardır. Navran ise (1967) yaptığı araştırmada, mutlu çiftlerin evliliklerinde, sorun yaşayan çiftlere göre daha fazla konuştuklarını, birbirlerini ve 
sorunlarını daha iyi anladıklarını belirlemiştir. Kocadere (1995), iyi ve kötü evliliklerin özelliklerini belirlemeye yönelik araştırmasında iyi evliliklerde eşlerin duygu, düşünce ve dertlerini birbirleriyle daha fazla paylaştıklarını; kötü evliliklerde önemli konulardaki kararların daha çok tek taraflı alındığını, iyi evliliklerde ise önemli konulardaki kararların birlikte alındı̆̆ını belirlemiştir. Bir değer olarak sorumluluk aileyi birarada tutan önemli değerlendendir ve bugün yeniden üzerinde düşünmeyi gerektirmektedir. BASAGM'ın (2010) yaptığı çalışma aile açısından sorumluluğun üzerinde yeniden düşünmeyi gerektirmektedir. BASAGM (2010) yaptığı araştırmada kadının ev içi rollerini öne çıkaran ve onunla sınırlayan "bir kadının asıl görevi çocuk bakımı ve ev işleridir" biçiminde ifade edilen anlayışın artık yaygın olarak kabul görmediği; bunun yerine erkeği de ev işlerinden sorumlu tutan eşitlikçi bir anlayışın öne çıktığı sonucuna ulaşmıştır. Sağlam (2014), ilköğretim öğrencilerinin anne ve babalarının birlikte yaşayanlarının aile birliğine daha çok önem verdikleri sonucuna ulaşmıştır. Bu durum, toplumun temeli olan aile birliğinin önemine dikkat çekmekte, bir değer olan aile birliğinin korunmasında değerlerin önemli rolü olduğu sonucunu ortaya koymaktadır. Araştırma sonucunda ailenin, değerlerin kazandırılmasında önemli bir kurum olduğu düşünülerek ebeveynlerin buna ilişkin farkındalıklarının artırılmasına yönelik çalışmaların yapılabileceği önerilmektedir.

\section{Kaynakça}

Akbaş, O. (2008). Sosyal Bilgilerde Değerler ve Öğretimi. B. Tay ve A. Öcal (Ed.). Özel Öğretim Yöntemleriyle Sosyal Bilgiler Öğretimi (s. 336-358). Ankara: Pegem Akademi Yayınları.

Annells, M. (2006). Triangulation of Qualitative Approaches: Hermeneutical Phenomenology and Grounded Theory. Journal of Advanced Nursing, 56(1), 55-61.

Başbakanlık Aile ve Sosyal Araştırmalar Genel Müdürlüğü (BASAGM). (2010). Türkiye'de Aile Değerleri Araştırması. Ankara: Manas Medya Planlama Reklam Hizmetleri San. Tic. Ltd. Şti.

Büyüköztürk, Ş., Kılıç-Çakmak, E., Akgün, Ö. E., Karadeniz, Ş. ve Demirel, F. (2014). Bilimsel Araştırma Yöntemleri. Ankara: Pegem Akademi Yayınları.

Çağlar, A. (2005). Okulöncesi Dönemde Değerler Eğitimi. (Editör: M. Sevinç). Erken Çocuklukta Gelişim ve Eğitimde Yeni Yaklaşımlar. İstanbul: Morpa Yayınları.

Çavdarcı, M. (2002). Türkiye'de Sosyal Değerlerin Aşınması. Yayımlanmamış yüksek lisans tezi. Süleyman Demirel Üniversitesi Sosyal Bilimler Enstitüsü, Isparta.

Celkan, H. Y. (1993). Eğitim Sosyolojisi. Erzurum: Atatürk Üniversitesi Yayınları.

Ekşi, H. ve Katılmış, A. (2016). Uygulama Örnekleriyle Değerler Eğitimi. Ankara: Nobel Yayınları.

Erdil, K. (1991). Aile Okulu. Ankara: Türkiye Diyanet Vakfı Yayınları.

Genç, S. Z. (2016). Eğitim Sürecinde Aile Okul ve Toplum. Ankara: Pegem Akademi Yayınları.

Güven, S. (1999). Toplum Bilim. Bursa: Ezgi Kitapevi.

Hestead J. M. ve Taylor, M. J. (1996). Values in Education and Education in Values. Bristol: USA The Falmer Press.

İş̧i, M. (2013). Sosyal Yapı ve Sosyal Değişme. İstanbul: Den Yayınları.

Kıncal, R. Y. (1999). Ailenin Eğitimsel Fonksiyonları. Erzurum: Atatürk Üniversitesi Yayınları.

Kocadere, M. (1995). İyi ve Kötü Evliliklerin Özelliklerini Belirlemeye Yönelik Betimsel Bir Çalışma. Yayımlanmamış yüksek lisans tezi. Ege Üniversitesi Sağıı Bilimleri Enstitüsü, İzmir.

Könezoğlu, B. (2006). Aile ve Ailenin Korunması. Yayınlanmamış yüksek lisans tezi. Ankara Üniversitesi Sosyal Bilimler Enstitüsü, Ankara.

Milli Eğitim Bakanlığı [MEB], (2005). Illköğretim Sosyal Bilgiler Dersi Öğretim Programı. Ankara: Ders Kitapları Müdürlüğ̈̈ Basımevi.

Navran, L. (1967). Communication and Adjustment in Marriage. Family Process, 6, 173-184.

Naylor, D. T. ve Diem, R. (1987). Elemantary and Middle School Social Studies. New York: Random House. 
Patton, M. Q. (1997). How to Use Qualitative Methods in Evaluation. Newbury Park, CA: SAGE Publications.

Rokeach, M. (1973). The Nature of Human Values. New York: Free Pres.

Sağlam, H. İ. (2008). Eğitimin Toplumsal Temelleri. A. Çiçek-Sağlam (Ed.), Eğitim Bilimine Giriş içinde (s. 95-126). Ankara: Maya Akademi.

Sağlam, H. İ. (2014). Aile Birliğini Önemseme Ölçeğinin Geliştirilmesi ve Öğrencilerin Aile Birliğini Önemseme Düzeylerinin İncelenmesi. Çağın Sorunları Karşısında Eğitim Sempozyumu Kitabı (s.363-388). Erzurum: Bayburt Üniversitesi Yayınları.

Şener, A. ve Terzioğlu, G. (2002). T.C. Başbakanlık Aile Araştırma Kurumu Başkanlığı: Ailede Eşler Arası Uyuma Etki Eden Faktörlerin Araştırılması. Ankara: Kardelen Ofset.

Tozlu, N. (2003). Eğitim Problemlerimiz Üzerine Düşünceler. 2. Baskı, Ankara: Mikro Yayınclık.

Uyanık-Balat, G. ve Balaban-Dağal, A. (2009). Okulöncesi Dönemde Değerler Eğitimi Etkinlikleri. Ankara: Kök Yayıncılık.

Yıldırım, A. ve Şimşek, H. (2011). Sosyal Bilimlerde Nitel Araştırma Yöntemleri. Ankara: SeçkinYayınevi.

Yıldırım, A. ve Şimşek, H. (2013). Sosyal Bilimlerde Nitel Araştırma Yöntemleri. Ankara: SeçkinYayınevi. 


\section{Extended Summary}

Family, the smallest unit of the society, is the place where the child is interactive, observes many things, learns by imitation, the foundations of his/her personality are laid. The communication, interaction method between the family members affects the child, shapes his/her personality. Family institution plays an important part in giving the values to the children such as love, respect, cooperation, solidarity, communication, loyalty (Sağlam, 2009). Family is the name of the holy place where all the national values are given to the child. Humane values such as humanity, virtue, mercy, cooperation and pity are forned in the family first. Family, at the same time, is a castle which prevents alienation and break up. Family is a mercy institution at the same time (Tozlu, 2003). Family is one of the most important societal institutions which continue their existence in every society throughout the history (Aydın, 2000). Because the society is formed by the families coming together. Continuity of the family is the continuity of the society at the same time. This study is made in order to determine the role of the values in protecting the conjugal community in light of the opinions of teachers. Therefore, the study tries to determine what is the secret of keeping the family members together and what is the role of love, respect, loyalty, responsibility and tolerance in the continuation of conjugal community.

The research is carried out within the scope of phenomenology pattern which is one of the qualitative research patterns. The study group of the research composes classroom and branch teachers who serve in Körfez county of Kocaeli province in 2014-2015 education year. Of these teachers, $68 \%$ is woman and $32 \%$ is man. Also, of these teachers who participate in the research, $66 \%$ is married and $34 \%$ is single. Half-structured interview form is used in the research. Data obtained from the teachers are analyzed by subjecting them to content analysis. Data are evaluated by the researchers seperately and encoded and the consistency between the encodings are determined as .91. In the research, while the results are being reported, direct quotations take place. Validity is obtained by making one-to-one quotations from class teachers related to themes and codes.

In this research which is made to determine the role of values in protecting conjugal community, it is concluded that the secret of keeping the family together is in the love, respect, patience and tolerance as a value and in the decision-making, communication and empathy as a skill. Also, it is determined that love, respect, loyalty, responsibility and tolerance values play very important part in protecting the conjugal community. This fact resembles the results of the research made by BASAGM (2010) in which the participants attach importance to their families in the ratio of $99.3 \%$ as a whole and the family institution is seen very important in Turkish society. This fact also resembles the research results which family, also a value, is placed in the centre of values area. In the mentioned research, participants display the importance attached to the family by agreeing highly with the expressions "the first place which should be consulted in case of physical and moral problems is the family" and "I can endure all kinds of troubles for my family's good". This fact also resembles the results of the research which is made by Sağlam (2014) to determine the importance level of conjugal community of primary school students. Similarly, Şener and Terzioğlu (2002) determines in their researches that marriage harmony points of both men and women raise significantly by increasing the sharing of feelings and opinions between the couples. Navran (1967) determines in his research that happy couples speak more than the couples who have troubles in their marriages and understand themselves and their problems better. Kocadere (1995) determines in his research made to determine the characteristics of good and bad marriages that couples in good marriages share their feelings, opinions and troubles more and in bad marriages important decisions are taken mostly unilaterally and in good marriages important decisions are taken jointly. Responsibility is one of the important values which keep the family together and it should be thought again today. The study made by BASAGM (2010) requires thinking again over the responsibility in terms of family. In the research, BASAGM (2010) concludes that the idea which highlights the roles of woman within the house and limits in this scope and which is expressed as "the main job of woman is child care and houseworks" is not accepted commonly any more, instead, the egalitarian idea which holds the man also responsible for the houseworks stands out. Sağlam (2014) concludes that mothers and fathers of primary school students who live together attach more importance to the conjugal community. This situation attracts attention to the importance of conjugal community which is the basis of society and concludes that values have important role in protecting the value of conjugal community. 